\title{
Lenin, Religion, and Theology, by Roland Boer
}

New Approaches to Religion and Power | New York: Palgrave Macmillan, 20I3 | 347 pages | ISBN: 978-I-I 37-323897 (hardcover) \$100.00 | ISBN: 978-I-I37-32390-3 (softcover) $\$ 40.00$

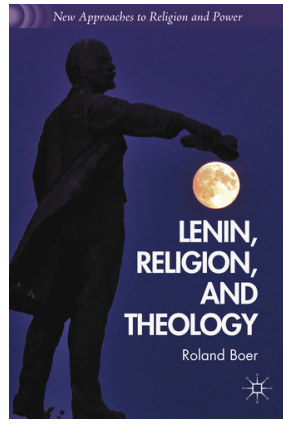

Any association between the Marxist revolutionary figure of Vladimir Lenin and Christian theology might seem tenuous at best. For the most part this book deals with the implicit- the theological dimensions hidden within Lenin's extensive works—and in this sense the author's background as a biblical scholar or textual excavator comes to the fore. Referring to a "passing comment" of Alain Badiou in which he analogizes the Apostle Paul to Lenin and Jesus Christ to Marx, Boer instead suggests thatif we must hold to the analogy—Lenin "comes closer to Christ than to Paul." The enigmatic sayings and parables of Jesus inspired Lenin to the point that he composed his own. Lenin was also immersed in Russian folklore which itself was infused with biblical imagery. Boer goes on to argue that this creativity was, in part, utilized during the veneration of Lenin after his death.

Having identified some tentative links between Lenin and theology in his introduction, Boer launches into a scrupulous exploration of Lenin's thought in search of further theological nuggets. In "Spiritual booze and the freedom of religion," for example, Boer contends that, in contrast to the widespread belief that Marxism is necessarily atheistic and that Lenin in particular held a contemptuous and superficially dismissive view of religion, Lenin's approach was, in fact, surprisingly complex and at times dialectical. For Boer, the simplistic view of Lenin as one who simply dismisses religion is regularly overstated. This point is well-illustrated by a number of examples and provides a platform for engagements in subsequent chapters. Nonetheless, it does feel as though Boer-perhaps the most prodigious writer in the field of biblical reception history-is occasionally reading against the grain (e.g., 2I-24).

On the negative front, Lenin extends Marx's view of religion as an indicator of socioeconomic exploitation; a coping mechanism to deal psychologically with the toils of oppression. As a hangover of feudalism, including the established church's interdependence with the state, Lenin goes one step further to assert that religion is also a cause of suffering. Opposition to organized 
religion, accordingly, takes on a political nuance. On the other hand, some of Lenin's writings actually reveal a "subtler approach to religion, a subtleness sometimes lost in the earthy, blunt, and polemical style of his writings" (13). In Boer's sights is a quote alluding to Marx's famous observation that religious suffering is the opium of the people. In Lenin's version, religion is described as "spiritual booze, in which the slaves of capital drown their human image, their demand for a life more or less worthy of man" (Lenin, "Socialism and Religion," I905, 83-84; cited in Boer, I4). Through some creative exegesis, Boer rounds out the multivalence of this saying: "alcohol is as complex a metaphor as opium, if not more so. It is both spiritual booze and divine vodka: Relief for the weary, succor to the oppressed, inescapable social mediator, it is also a source of addiction, dulling of the senses, and dissipater of strength and resolve." According to Boer, "Religion-as-grog opens up a far greater complexity concerning religion in Lenin's thought that one may at first have thought" (I 7 ).

In the next chapter, Boer turns his attention to explicit biblical references in Lenin's works. The chapter is effective at presenting how and why a political figure like Lenin would utilize biblical texts in the construction and support of political arguments. Boer begins with the parable of the wheat and tares (Mt I 3:24-30) which Lenin draws on in his rethinking of the organization of the Russian Social Democratic Labour Party. Lenin uses the metaphor of separating wheat from the tares, or the good from the bad, to the crucial issue of whether the communist movement should work within strictly legal frameworks. For instance, should his disciples favour trade unions and worker movements over underground movements and agitators that seek to induce bigger gains for the working class? Boer observes that Lenin favoured both and did not see either as mutually exclusive. In fact, in Lenin's reinterpretation, the tares are those who argue for legal organizations alone. Boer then briefly considers other biblical metaphors, including various parables to do with soil, agriculture, and lost sheep, which are utilized by Lenin to flesh out arguments and prescriptions concerning the early communist movement. Lenin also created a number of his own parables, sometimes drawing on Russian folklore and literature in their composition. Why does it matter that Lenin used the Bible in such a way? While at some level it is easy to identify Lenin's use of the Bible as stemming from his general cultural awareness of which the Bible was an important cultural artefact, Boer pushes further to suggest that Lenin's concentration on agricultural texts in the Gospels is due precisely to their use of earthy, peasant and working-class 
language and Lenin's ambition to articulate the political struggle in concrete, everyday terms.

In chapter three, Boer chronicles Lenin's engagements with his Christian adversaries: first, the Christian socialism of Father Georgi Gapon, a provocateur who incited unrest immediately preceding the 1905 revolution; second, Leo Tolstoy, a favourite author of Lenin whom he also knew personally; and finally, the "God-builders," who sought to promote the affinities between Marxism and religion. According to Boer, the appeal of Tolstoy's work to the political left comes from his advocacy of peasant values: "feeding into a romanticizing of peasant life and village-commune ... [and] as offering a peculiarly Russian and thereby alternative path to socialism" (63). Tolstoy's response is at once a critique of his situation as well as an essentially religious solution found in the simple forms of earliest Christianity. Boer notes that Lenin found Tolstoy's work appealing for its contradictions: the critique of economic exploitation is incisive, but the proposed solution of a simplified Christianity largely disengaged from politics is regarded as problematic. According to Boer, Lenin failed, however, to recognize that the depth of Tolstoy's critique of economic exploitation is part of the tradition of Christian communism and its revolutionary rather than regressive outlook.

While Lenin was tentatively open to the Christian socialists, he opposed the God-builders. Boer focuses in particular on the work of Lunacharsky, a member of the Bolsheviks who, in his two-volume Religion and Socialism (I908-I I), controversially speaks of Marxism as a new religion. Lenin denounced God-building and argued that, while one is free to join the party if one is a believer, one must not proselytise within the party. Lenin's attack against God-building also came indirectly through his engagement with the increasing influence of empirio-criticism. The chapter concludes with an analysis of Lenin's Materialism and Empirio-Criticism (1909), a text which attacks some of the God-builders at length. Empirio-criticism maintained that the only knowledge available comes from sensation. Accordingly, knowledge should be restricted to experience. Lenin's opposition was as much political as it was philosophical. The basic problem was that it relied upon a radically materialist empiricism, based on sense-perception, which would inevitably lead to mysticism, fideism, and clericalism. Boer's engagement with the philosophical school of empirio-criticism and its wider context of phenomenology is extended in the following chapter, "Returning to Hegel: Revolution, Idealism, and God." Following the outbreak of the First World War, Lenin read Hegel's The Science of Logic in Berne. A couple of aspects 
stand out for Boer: first, the recasting of the relation between subjective and objective approaches that entailed a renewed sense of subjective revolutionary intervention; second, Lenin's encounter with Hegelian idealism appears to have influenced his thinking on the revolutionary possibilities of religion and, in some cases, God-building.

In chapter five, "Miracles Can Happen," Boer takes as a point of departure a quote from Lenin that equates revolution with a miracle: "In certain respects, a revolution is a miracle." The chapter then proceeds to explore the theological aspects of revolution. Boer writes that a miracle is "a point of contact between two seemingly incommensurable worlds.... In Lenin's appropriation, the two worlds are no longer heaven and earth but those of spontaneity and organization, between the expected and the unexpected" (I 35). The moment of revolution occurs without forewarning. The miracle, Boer suggests, is a crucial dimension of Lenin's approach to revolution; the miracle of revolution refers to the bending of transcendence to immanence, in which humans become the agents of change. For some curious reason this was for me the standout chapter in Boer's book. Perhaps it is the appeal of a simple but unexpected junction between theology and socialism that is, at the same time, not overly forced. The remainder of the chapter examines the theological term kairos which signifies the point of crisis or end time, and the right moment for revolution. The tension between transcendence and immanence embodied in the miracle is also discussed in terms of the apparent conflict between reform and revolution. A miracle, for Lenin, is far more than a metaphor for religion. In bending transcendence to immanence, thereby emphasizing human agency, the miracle is a site of a dialectic between spontaneity and organization. In other words, one seeks to organize in order for the spontaneous to occur; the unplanned revolution will take place because of prior organization.

Within this book religion more-or-less means Christianity, although this limitation is not always signposted. At times, Boer moves from very specific discussions about Christianity to abstractions about religion more generally. Given that Christianity was the dominant religion in Russia during Lenin's lifetime, it is understandable that any concern with religion would probably involve Christianity. But it would have been equally interesting, by way of comparison, to observe how Lenin's theology might function in terms of the sociology of religion itself. Boer comes close to engaging this in his concluding chapter on Lenin's veneration. The so-called Lenin "cult" is an unfortunate label, according to Boer, because it suggests the functioning of 
secular religion in a pejorative manner. While the main focus of this chapter is on what happened after Lenin's death, Boer starts his analysis in the works of Lenin himself. He discusses the Russian Orthodox understandings of saints, prophets, and martyrs, according to Lenin's understanding, in addition to Lenin's construction of bodies, corpses and diseases. The reason for veneration is neither the revival of suppressed religion, as often supposed, nor a demonstration that religion is somehow innate to human society. Rather, Boer contends that Lenin's veneration provided a form of extra-economic compulsion; in other words, an ideological means of encouraging workers to invest in a communist system in which the compulsions and incentives of capitalism no longer apply.

The main insights in Lenin, Religion, and Theology are mediated by Boer's detailed discussions of primary texts. Indeed, Boer claims to have read Lenin's entire corpus in preparation for this book. At times, Boer's training as a biblical critic also comes into sharp focus (e.g., I 4-I 5, 32-33) and while the exegesis and commentary may not appeal to everybody interested in Lenin and religion, it certainly uncovers the complexities and contradictions within Lenin's own thought. What the book lacks, in my opinion, are the particulars of Lenin's religious biography. Details of Lenin's early religious encounters or experiences that possibly influenced him in later life, including his family's entanglement with the Lutheran church and his possible Jewish descent, remain unexplored. When Lenin was fifteen years old, for example, his father suddenly died of a heart attack. It is thought that this event had a shattering effect on his Christian faith and enabled him to become immersed in the philosophy of materialism only a few years later. Boer is silent on these details. Elements of biography do seep through in places, but it is difficult to gain from Boer's study a well-rounded picture of the role that religion played (or did not play) in Lenin's upbringing and later life.

I began this review by noting that any connection between Lenin and theology might seem tenuous at best. After reading this book one could probably still hold the same opinion, although with a more enriched understanding of where theology and Lenin's thought (including Marxism more generally) might overlap. For this reason the book is a valuable resource in determining how religion and revolution have historically clashed and/or converged and how they will continue to do so in the future. 